\title{
ANALISIS PENGARUH FEMALE EXECUTIVE TERHADAP MANAJEMEN LABA (STUDI PADA PERUSAHAAN MANUFAKTUR YANG TERDAFTAR DI BURSA EFEK INDONESIA TAHUN 2016 - 2018)
}

\author{
Baiq Aulia Sulhia \\ baiqaulia1234@gmail.com \\ Jurusan Akuntansi Fakultas Ekonomi dan Bisnis Universitas Mataram \\ Eni Indriani \\ eni.indriani@unram.ac.id \\ Jurusan Akuntansi Fakultas Ekonomi dan Bisnis Universitas Mataram \\ Isnawati \\ isnawati.isna@unram.ac.id \\ Jurusan Akuntansi Fakultas Ekonomi dan Bisnis Universitas Mataram
}

\begin{abstract}
ABSTRAK
Penelitian ini menguji pengaruh female executive terhadap manajemen laba pada perusahaan manufaktur tahun 2016 - 2018 dan perbedaan female executive dalam menerapkan manajemen laba baik melalui pendekatan akrual maupun riil. Manajemen laba akrual dan manajemen laba riil adalah proxy yang digunakan dalam penelitian ini untuk mengukur manajemen laba. Pengujian dilakukan pada 50 perusahaan manufaktur yang terdaftar di Bursa Efek Indonesia selama tahun 2016 - 2018. Hasil Penelitian ini menunjukkan bahwa female executive berpengaruh terhadap manajemen laba riil, sedangkan female executive tidak berpengaruh terhadap manajemen laba akrual, dan tidak ada perbedaan female executive dalam menerapkan manajemen laba baik melalui pendekatan akrual. Temuan penelitian ini mengindikasikan bahwa keberadaan female executive di suatu perusahaan dapat saja menurunkan tingkat manajemen laba melalui pendekatan riil pada perusahaan manufaktur. Implikasi penelitian ini memberikan gagasan bahwa adanya female executive di suatu perusahaan dapat menekankan tingkat manajemen laba melalui pendekatan riil, implikasi penting lainnya mengarah pada semakin banyaknya female executive disuatu perusahaan dapat menurunkan tingkat manajemen laba melalui pendekatan riil.
\end{abstract}

Kata Kunci: $\quad$ Manajemen Laba, Manajemen Laba Akrual, Manajemen Laba Riil, Female executive.

\section{ABSTRACT}

This study examines the effect of female executives on earnings management in manufacturing companies in 2016 - 2018 and differences in female executives in implementing earnings management through the accrual and real approaches. Accrual earnings management and real earnings management are proxies used in this study to measure earnings management. Tests were conducted on 50 manufacturing companies listed on the Indonesia Stock Exchange during 2016 - 2018. The results of this study indicate that female executives have an effect on real earnings management, while female executives have no effect on accrual earnings management, and there are no female executive differences in implementing earnings management either through the accrual approach. The findings of this study indicate that the presence of female executives in a company can reduce the level of earnings management through a real approach to manufacturing companies. The implications of this study provide the idea that the existence of a female executive in a company can emphasize the level of earnings management through a real approach, another important implication leads to the increasing number of female executives in a company can reduce the level of earnings management through a real approach.

Keywords: $\quad$ Earnings Management, Discretionary Accruals, Real Earnings Management, Female executive 


\section{PENDAHULUAN}

Manajemen laba merupakan upaya manajer perusahaan untuk mengintervensi atau mempengaruhi informasi-informasi dalam laporan keuangan dengan tujuan mengelabui stakeholder yang ingin mengetahui kinerja dan kondisi perusahaan (Sulistyanto, 2014:6). Sedangkan menurut Scott (2011:423) dalam Agustia (2013) adalah manajemen laba merupakan keputusan dari manajer untuk memilih kebijakan akuntansi tertentu yang dianggap bisa mencapai tujuan yang diinginkan, baik itu untuk meningkatkan laba atau mengurangi tingkat kerugian yang dilaporkan.

Perbedaan istilah manajemen laba menyebabkan setiap pihak yang concern pada masalah aktivitas rekayasa manajerial ini mencoba untuk mendefinisikannya, baik dari pemahaman positif maupun negatif. Ada pihak yang mendefinisikan manajemen laba sebagai kecurangan, sedangkan pihak lain mendefinisikannya sebagai aktivitas yang lumrah dilakukan manajer dalam menyusun laporan keuangan (Sulistyanto, 2014:4).

Manajemen laba menurut para praktisi, yaitu pelaku ekonomi, pemerintah, asosiasi profesi, dan regulator lainnya merupakan sebuah kecurangan karena secara sadar seorang manajer mempermainkan angka-angka dalam laporan keuangan sesuai dengan tujuan yang ingin di capainya agar stakeholder yang ingin mengetahui kondisi ekonomi perusahaan tertipu karena memperoleh informasi palsu. Sementara para akademisi, termasuk peneliti berargumen bahwa manajemen laba juga merupakan dampak dari keleluasaan seorang manajer untuk memilih dan menggunakan metode akuntansi tertentu ketika mencatat dan menyusun informasi dalam laporan keuangan. Hal ini disebabkan ada beragam metode dan prosedur akuntansi yang diakui dan diterima dalam prinsip akuntansi berterima umum (Sulistyanto, 2014:4).

Dari kedua pendapat tersebut baik itu dari para praktisi maupun para akademisi sepakat untuk menilai bahwa manajemen laba ini adalah upaya untuk mengubah, menyembunyikan dan menunda informasi keuangan (Sulistyanto, 2014:4). Beberapa pendekatan dapat dilakukan dalam mendeteksi manajemen laba (earning management) yaitu manajemen laba dengan pendekatan akrual (accrual earning management) dan pendekatan riil (real earning management).

Manajemen laba akrual merupakan metode manajemen laba yang dilakukan oleh perusahaan dengan memanfaatkan kebijakan akrual. Manajemen laba akrual ini hanya dapat dilakukan oleh manajemen pada akhir periode ketika manajemen melihat laba yang belum direkayasa, sehingga dapat menentukan besaran rekayasa terhadap akrual diskresioner yang diperlukan untuk mencapai target pencapaian laba. Roychowdhury (2006) menyimpulkan bahwa manajemen laba dengan hanya mendasarkan pada pengaturan akrual saja mungkin menjadi tidak valid, maka dari itu dalam mendeteksi manajemen laba juga dapat dilakukan dengan pendekatan riil

Manajemen laba riil merupakan rekayasa yang dilakukan oleh manajemen melalui aktivitas perusahaan sehari-hari selama periode akuntansi, tanpa menunggu akhir periode. Manajemen laba riil dapat ditinjau menggunakan tiga pendekatan, yaitu melalui operasi arus kas abnormal, biaya produksi abnormal dan biaya-biaya diskresioner abnormal (Roychowdhury, 2006). Ada beberapa faktor yang dapat mempengaruhi praktik manajemen laba, beberapa diantara variabelvariabel tersebut yang sering digunakan dalam penelitian baik dalam maupun luar negeri seperti, ukuran perusahaan, reputasi auditor, struktur kepemilikan perusahaan, dan financial leverage (Susanto dan Jamaluddin, 2017).

Perilaku manajemen laba dapat dilihat dari berbagai aspek terutama dalam lingkungan tata kelola perusahaan, dimana salah satu isu tata kelola perusahaan yang 


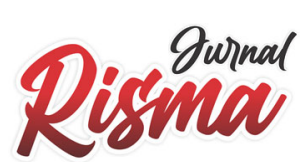

Vol. 1 No. 3 September 2021

berkembang beberapa tahun terakhir adalah isu board diversity berbasis gender (Rakhman dan Kholida, 2018). Dalam manajemen perusahaan, pemimpin eksekutif yang terlibat dalam pelaporan keuangan antara lain Chief Official Officer (CEO), Chief Financial Officer (CFO), dan Dewan Komisaris. CEO dan CFO terlibat karena keduanya merupakan pihak yang bertanggung jawab dan menandatangani laporan keuangan (Setyaningrum dkk, 2020). Sedangkan dewan komisaris terlibat secara tidak langsung, karena dewan komisaris berperan dalam fungsi pengawasan serta review atas informasi yang disajikan.

Terkait dengan manajemen laba, perbedaan gender dari manajemen puncak perusahaan tentunya dapat diasumsikan akan memiliki pengaruh pada praktik manajemen laba. Sifat pria yang lebih agresif, dan senang mengambil peluang maupun risiko diduga akan meningkatkan tingkat manajemen laba di perusahaan, sedangkan sifat wanita yang merupakan kebalikan dari sifat pria, diharapkan mampu mengurangi tingkat manajemen laba di perusahaan.

Adanya praktik manajemen laba tidak dapat mencerminkan kondisi perusahaan yang sesungguhnya. Hal ini dapat menyesatkan pemakai laporan keuangan khususnya investor, dimana biasanya para investor akan menjadikan laba perusahaan sebagai tolok ukur keputusan investasi mereka, dan diharapkan dari adanya laba yang tinggi maka diperoleh tingkat pengembalian hasil yang tinggi juga (Kurniawati, 2018).

Beberapa peneliti sudah melakukan penelitian dan menemukan hasil yang berbeda, Penelitian yang dilakukan oleh Damayanti, dkk (2020) hasil penelitian menunjukkan CEO Wanita berpengaruh terhadap manajemen laba, sedangkan CFO wanita dan dewan direksi tidak berpengaruh terhadap manajemen laba. Penelitian yang dilakukan oleh Purnama dan Suciani (2020) menunjukkan bahwa Female CEO, CFO, dan Dewan Komisaris tidak berpengaruh terhadap manajemen laba. Penelitian yang dilakukan oleh Firmansyah dan Ferry (2017) menunjukkan bahwa adopsi IFRS berpengaruh positif terhadap manajemen laba akrual. Selanjutnya, adopsi IFRS tidak berpengaruh terhadap manajemen laba riil. Hal ini menunjukkan bahwa tidak ada pergeseran perilaku manajer dari manajemen laba akrual menjadi manajemen laba riil setelah adopsi IFRS.

Tujuan Penelitian Berdasarkan pembahasan yang telah diuraikan di atas maka tujuan penelitian ini adalah sebagai berikut:

1. Untuk mengetahui pengaruh Female executive terhadap Manajemen Laba dengan pendekatan Akrual

2. Untuk mengetahui pengaruh Female executive terhadap Manajemen Laba dengan pendekatan Riil

3. Untuk mengetahui perbedaan pengaruh Female executive terhadap Manajemen Laba dengan pendekatan Akrual dan Riil

\section{KAJIAN PUSTAKA}

Agency Theory

Agency Theory menjelaskan tentang hubungan antara manajemen (agen) dengan pemegang saham (prinsipal). Jensen dan Mecking (1976) mendefinisikan hubungan keagenan sebagai kontrak di mana satu orang atau lebih (prinsipal) melibatkan orang lain (agen) untuk melakukan tindakan ekonomi demi kepentingan prinsipal dan prinsipal juga memberikan wewenang pembuatan keputusan kepada agen dengan asumsi bahwa agen akan bekerja demi kepentingan prinsipal dan memaksimalkan keuntungan prinsipal.

Konsep Agency Theory menyatakan bahwa praktik manajemen laba dipengaruhi oleh konflik kepentingan yang timbul diantara manajemen dan pemilik ketika setiap 
pihak berusaha untuk mempertahankan tingkat kemakmuran yang dikehendakinya dan mencapai tujuan masing-masing pihak. Pemilik menginginkan retun yang tinggi atas investasinya, sedangkan manajemen memiliki kepentingan untuk mendapatkan kompensasi yang besar atas hasil kerjanya. Perbedaan tujuan itulah yang menyebabkan terjadinya conflict of interest di antara pihak agen dan principal (Ardyanti, 2020). Conflict of interest ini juga muncul karena adanya perilaku oportunistik dari agent, yaitu perilaku manajemen untuk memaksimumkan kesejahteraannya sendiri yang berlawanan dengan kepentingan principal.

Dalam hubungan antara agen dan prinsipal, akan timbul masalah jika terdapat informasi yang asimetri. Informasi yang asimetri merupakan ketidakseimbangan informasi yang diketahui antara agen dan principal. Dikarenakan adanya asimetri informasi antara pemilik dan pengelola menyebabkan adanya permasalahan yang muncul yaitu dari keinginan manajer yang cenderung bertindak untuk mengoptimalkan kesejahteraan pribadi dengan mengelabui stakeholder lain yang tidak mempunyai akses dan sumber informasi yang memadai.

Hubungan agensi antara pemilik dan pengelola perusahaan seharusnya menghasilkan hubungan simbiosis mutualisme yang menguntungkan semua pihak, khususnya apabila setiap pihak menjalankan hak dan kewajibannya secara bertanggung jawab. Namun yang terjadi justru sebaliknya, yaitu munculnya permasalahan agensi (agency problem) antara pemilik dan pengelola perusahaan. Permasalahan ini muncul karena ada pihak yang lebih mengutamakan kepentingan pribadi meskipun merugikan pihak lain. Terkait dengan female executive, sifat wanita yang jujur, kehati-hatian dan tidak berani mengambil resiko diharapkan mampu mengurangi adanya asimetri informasi di suatu perusahaan.

\section{Manajemen Laba \\ Definisi Manajemen Laba}

Manajemen laba merupakan upaya manajer perusahaan untuk menyembunyikan, menunda dan mengubah informasi-informasi dalam laporan keuangan. Menurut Davidson et al, (1989) manajemen laba merupakan proses untuk mengambil langkah tertentu yang disengaja dalam batas-batas prinsip akuntansi berterima umum untuk menghasilkan tingkat yang diinginkan dari laba yang dilaporkan (Sulistyanto, 2014:48).

\section{Motivasi Manajemen Laba}

Menurut Sulistyanto (2014:63) ada tiga motivasi manajemen dalam melakukan manajemen laba yaitu sebagai berikut:

\section{Bonus Plan Hypothesis}

Menyatakan bahwa rencana bonus atau kompensasi manajerial akan cenderung memilih menggunakan metode-metode akuntansi yang akan membuat laba yang dilaporkannya menjadi lebih tinggi. Motivasi bonus merupakan dorongan bagi manajer dalam melaporkan laba yang diperolehnya untuk memperoleh bonus yang dihitung atas dasar laba.

\section{Debt (Equity) Hypothesis}

Menyatakan bahwa perusahaan yang mempunyai rasio antara utang dan ekuitas lebih besar, cenderung memilih dan menggunakan metode-metode akuntansi dengan laporan laba yang lebih tinggi serta cenderung melanggar perjanjian utang apabila ada manfaat dan keuntungan tertentu yang dapat diperoleh, keuntungan tersebut berupa permainan laba agar kewajiban utang-piutang dapat ditunda untuk periode berikutnya. 


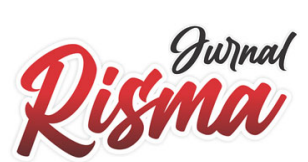

Vol. 1 No. 3 September 2021

\section{Political Cost Hypothesis}

Manajer akan mempermainkan laba agar kewajiban pembayaran tidak terlalu tinggi sehingga alokasi laba sesuai dengan kemauan perusahaan. Dengan menggunakan laba sebagai dasar perhitungan pajak ini akan membuat semakin besar laba yang diperoleh perusaahaan semakin besar pula pajak yang harus dibayarkan kepada pemerintah.

\section{Pola Manajemen Laba}

Menurut Sulistyanto (2014:177) ada beberapa pola yang dapat dilakukan dalam manajemen laba yaitu sebagai berikut:

1. Penaikkan Laba (Income Increasing), Merupakan upaya perusahaan mengatur agar laba periode berjalan menjadi lebih tinggi daripada laba sesungguhnya.

2. Penurunan Laba (Income Decreasing), Merupakan upaya perusahaan mengatur laba periode berjalan menjadi lebih rendah daripada laba sesungguhnya.

3. Perataan Laba (Income Smoothing), Merupakan upaya perusahaan mengatur labanya agar relatif sama selama beberapa periode.

\section{Klasifikasi Manajemen Laba}

Manajemen Laba dapat dilakukan melalui dua cara yaitu melalui manajemen laba akrual dan melalui pendekatan riil.

\section{Manajemen Laba Akrual}

Manajemen laba dilakukan dengan mempermainkan komponen-komponen akrual dalam laporan keuangan, sebab akrual meruapakan komponen yang mudah untuk dipermainkan sesuai dengan keinginan orang yang melakukan pencatatan transaksi dan menyusun laporan keuangan. Manajemen laba berbasis akrual dilakukan karena adanya keleluasaan kebijakan dari manajemen dalam menentukan suatu praktik akuntansi. Komponen akrual tidak memerlukan bukti kas secara fisik yang berarti tidak harus disertai dengan adanya kas yang diterima atau dikeluarkan perusahaan.

\section{Manajemen Laba Riil}

Praktik manajemen laba yang mengarah pada aktivitas operasional riil dikenal sebagai manajemen laba riil (real earning management). Roychowdhury (2006) mendefinisikan manajemen laba riil sebagai berikut "management actions that deviate from normal business practice, undertaken with the primary objective of meetings certain earnings thresholds". Hal ini berarti manajemen laba riil adalah tindakan-tindakan manajemen yang menyimpang dari praktek bisnis yang normal yang dilakukan dengan tujuan utama untuk mencapai target laba (Ningsih, 2015). Dalam mendeteksi manajemen laba riil yang dilakukan oleh perusahaan, (Roychowdhury, 2006; Cohen dan Zarowin, 2010). manajemen laba riil dapat dilakukan dengan 3 (tiga) cara yaitu:

a. Rekayasa Penjualan, Rekayasa penjualan merupakan usaha manajemen dalam meningkatkan penjualan secara temporer dalam periode tertentu dengan menawarkan diskon harga, produk secara berlebihan atau memberikan persyaratan kredit yang lebih lunak.

b. Mengurangi beban-beban diskresionari (dicretionary expenditures), Perusahaan menurunkan discretionary expenditures seperti beban penelitian dan pengembangan, iklan, penjualan, adminstrasi dan umum.

c. Produksi yang berlebihan (overproduction), Untuk meningkatkan laba, manajer perusahaan dapat memproduksi lebih banyak daripada yang diperlukan

\section{Female executive}

Meninjau dari litelatur psikologi dan penelitian manajemen bahwa terdapat perbedaan antara pria dan wanita dalam gaya memimpin suatu perusahaan. Perbedaan dapat dilihat dari cara berkomunikasi, sikap kehati-hatian, dan pengambilan keputusan pada suatu 
tindakan (Peni dan Vahamaa, 2010). Diversitas gender umumnya didasarkan terhadap perbedaan antara pria dan wanita berdasarkan sifat, kebiasaan, dan peran yang dibuat oleh masyarakat. Diversitas gender atau keragaman gender dalam penelitian ini diproksi dengan keberadaan wanita dalam jajaran dewan komisaris dan dewan direksi. Keberagaman gender dalam manajemen puncak perusahaan dapat mendorong keunggulan bersaing dibandingkan dengan perusahaan yang tidak memiliki keberagaman jenis kelamin (Erhardt et al, 2003). Keberagaman gender dalam manajemen puncak juga dapat berpengaruh terhadap pelaporan keuangan suatu perusahaan (Krishnan dan Parsons, 2008).

\section{Chief Executive Official (CEO)}

Chief executive officer (CEO) lebih dikenal dengan sebutan direktur utama atau presiden direktur, merupakan posisi tertinggi dalam jajaran eksekutif yang bertanggung jawab atas seluruh kegiatan operasional perusahaan dan menjadi salah satu posisi yang paling penting dalam perusahaan, sehingga posisi ini tidak bisa diisi oleh sembarang orang.

\section{Chief Financial Officer (CFO)}

Chief Financial Officer (CFO) adalah jabatan di suatu perusahaan yang memiliki tanggung jawab utama untuk mengelola keuangan perusahaan, dan merupakan posisi yang bertanggungjawab dalam mengelola risiko pada bidang keuangan, dimana CFO juga bertanggungjawab atas pencatatan dan pelaporan laporan keuangan yang ada pada perusahaan.

\section{Dewan Komisaris}

Dewan komisaris merupakan sekelompok anggota dewan yang ditunjuk oleh pemegang saham yang bertugas untuk mengawasi proses kegiatan usaha suatu perusahaan dan memberikan nasehat kepada direktur perusahaan.

\section{Pengembangan dan Perumusan Hipotesis}

Pengaruh Female executive terhadap Manajemen Laba melalui pendekatan Akrual

Manajemen Laba Akrual merupakan manajemen laba yang dilakukan dengan mempermainkan komponen-komponen akrual dalam laporan keuangan, sebab pada komponen akrual dapat dilakukan permainan angka melalui metode akuntansi yang digunakan sesuai dengan keinginan orang yang melakukan pencatatan dan penyusunan laporan keuangan. Dimana dalam penelitian in mengukur manajemen laba akrual menggunakan proxy discretionary accruals.

Terkait peran eksekutif wanita dalam manajemen laba, diharapkan sifat wanita yang cenderung lebih patuh terhadap peraturan, pasif, dan lebih memilih untuk menghindari risiko dapat menurunkan tingkat manajemen laba. Penelitian yang dilakukan oleh Damayanti, dkk (2020) berhasil membuktikan bahwa manajemen laba akrual berhasil dipengaruhi oleh female executive melalui Chief Official Officer (CEO). Berdasarkan penjelasan di atas maka peneliti menarik hipotesis sementara yaitu:

H1 : Female executive berpengaruh terhadap Manajemen Laba melalui pendekatan Akrual

\section{Pengaruh Female executive terhadap Manajemen Laba melalui pendekatan Riil}

Manajemen laba melalui pendekatan riil didefinisikan sebagai penyimpangan dari aktivitas operasi normal perusahaan yang dimotivasi oleh keinginan manajemen untuk memberikan pemahaman yang salah kepada pemangku kepentingan bahwa tujuan pelaporan keuangan tertentu telah dicapai melalui aktivitas operasi normal perusahaan (Roychowdhury, 2006).

Terkait dengan eksekutif wanita, sifat wanita yang lebih berhati-hati dan lebih memiliki standar etika yang lebih tinggi dapat diharapkan mampu meredam motivasi 


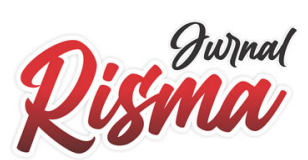

Vol. 1 No. 3 September 2021

untuk melakukan manajemen laba. Penelitian yang dilakukan Fransisca dan Hery (2015) berhasil membuktikan bahwa Chief financial officer wanita berpengaruh negatif secara signifikan pada real earnings management melalui arus kas kegiatan operasi. Dari uraian tersebut, maka hipotesis penelitian dapat dinyatakan sebagai berikut :

$\mathrm{H} 2$ : Female executive berpengaruh terhadap Manajemen Laba melalui pendekatan Riil

\section{Perbedaan Pengaruh Female executive terhadap Manajemen Laba melalui pendekatan Akrual dan Riil}

Rekayasa laba dengan pendekatan akrual merupakan rekayasa laba dengan menggunakan proxy discretionary accrual yang tidak memiliki pengaruh terhadap aliran kas secara langsung. Rekayasa laba akrual dilakukan pada akhir periode ketika manajer mengetahui laba sebelum direkayasa sehingga dapat mengetahui berapa besar rekayasa yang diperlukan agar target laba tercapai. Manajemen laba dengan pendekatan riil dilakukan oleh manajemen melalui aktivitas perusahaan sehari-hari selama periode akuntansi berjalan dengan tujuan tertentu yaitu memenuhi target laba tertentu atau untuk menghindari kerugian.

Terkait dengan eksekutif wanita, sifat wanita yang cenderung untuk lebih menghindari risiko dibanding lakilaki dalam hal pengambilan keputusan keuangan diharapkan dapat memberikan jawaban sementara terhadap perbedaan manajemen laba yang dilakukan baik dengan pendekatan akrual maupun riil. Penelitian yang dilakukan oleh Murdani dan Nurmala (2014) penelitian ini menunjukkan terdapat perbedaan manajemen laba riil pada tahun 2011 dan manajemen laba riil pada tahun 2013 dari subyek penelitian sejumlah 104 perusahaan manufaktur. Berdasarkan uraian diatas, maka hipotesis penelitian dapat dinyatakan sebagai berikut:

H3 : Terdapat perbedaan pengaruh Female executive terhadap Manajemen Laba melalui pendekatan Akrual dan Riil

\section{METODE PENELITIAN}

\section{Jenis Penelitian}

Jenis penelitian yang digunakan dalam penelitian ini adalah penelitian asosiatif kausal dengan pendekatan kuantitatif. Menurut Sugiyono (2012: 13) penelitian asosiatif yaitu, penelitian yang bersifat menanyakan hubungan antara dua variable atau lebih. Sedangkan hubungan kausal adalah hubungan yang bersifat sebab akibat. Jadi ada variabel independen (variabel yang mempengaruhi) dan dependen (dipengaruhi). Pendekatan ini disebut pendekatan kuantitatif karena data penelitian berupa angka angka dan analisis menggunakan statistik.

\section{Lokasi dan Waktu Penelitian}

Penelitian ini dilakukan pada industri manufaktur yang terdaftar di Bursa Efek Indonesia (BEI) pada tahun 2016-2018. Waktu penelitian adalah pada saat pengumpulan dan analisis data.

\section{Populasi dan Sampel Penelitian}

Populasi yang digunakan dalam penelitian ini adalah seluruh perusahaan manufaktur yang terdaftar di Bursa Efek Indonesia tahun 2016 - 2018. Dan metode pengambilan sampel yang digunakan dalam penelitian ini adalah Purposive Sampling. Sampling Purposive adalah teknik penentuan dengan pertimbangan tertentu (Sugiyono, 2012 : 85). Sampel dalam penelitian ini adalah perusahaan manufaktur yang memenuhi kriteria sebagai berikut :

1. Perusahaan manufaktur yang terdaftar di Bursaa Efek Indonesia tahun 2016 - 2018 
2. Perusahaan Manufaktur yang tidak Delisting, Relisting, dan tidak melakukan IPO selama tahun 2016 - 2018

3. Perusahaan manufaktur yang menerbitkan laporan keuangannya dengan mata uang Rupiah

4. Perusahaan yang memiliki Female executive dalam manajemen puncak selama tahun $2016-2018$

\begin{tabular}{llc}
\hline No. & \multicolumn{1}{c}{ Kriteria } & Jumlah \\
\hline 1. & $\begin{array}{l}\text { Perusahaan manufaktur yang terdaftar di Bursa Efek } \\
\text { Indonesia tahun 2016 - 2018 }\end{array}$ & 152 \\
\hline 2. & $\begin{array}{l}\text { Perusahaan yang Delisting, Relisting, dan melakukan IPO } \\
\text { selama tahun 2016 - 2018 }\end{array}$ & $(13)$ \\
\hline 3. & $\begin{array}{l}\text { Perusahaan manufaktur yang menerbitkan laporan keuangan } \\
\text { dengan mata uang asing }\end{array}$ & $(15)$ \\
\hline $4 . \quad \begin{array}{l}\text { Perusahaan manufaktur yang tidak memiliki Female } \\
\text { executive dalam manajemen puncak selama tahun 2016 - }\end{array}$ & $(74)$ \\
& 2018 & 50 \\
\hline Jumlah Sampel & 150 \\
\hline Jumlah Sampel x 3 Tahun
\end{tabular}

Tabel 1. Rincian Jumlah Sampel

\section{Jenis dan Sumber Data}

Jenis data yang digunakan dalam penelitian ini adalah data kuantitatif. Sumber data dalam penelitian ini adalah data sekunder. Data sekunder yang digunakan dalam penelitian ini adalah laporan keuangan yang bisa didapatkan dari Bursa Efek Indonesia (BEI) dengan mengakses web www.idx.co.id.

\section{Variabel Penelitian}

\section{Variabel Terikat (Dependent Variable)}

\section{Manajemen Laba Akrual}

Praktik manajemen laba akrual dilakukan dengan mempermainkan komponen-komponen akrual dalam laporan keuangan, sebab akrual merupakan komponen yang mudah untuk dipermainkan sesuai keinginan orang yang melakukan pencatatan dan penyusunan laporan keuangan (Sulistyanto, 2008). Praktik laba yang bersifat akrual atau biasa disebut manajemen laba akrual dalam penelitian ini diukur dengan model Jones yang dimodifikasi (Jones Modified Model) oleh Dechow et al. (1995) untuk menghitung discretionary accruals. Perhitungan discretionary accruals dihitung dengan cara sebagai berikut:

1. Menentukan nilai total akrual dengan formulasi:

$$
T A_{i t}=N I_{i t}+C F O_{i t}
$$

2. Menentukan nilai parameter $\alpha 1, \alpha 2, \alpha 3$ menggunakan Jones Model (1991), dengan formulasi :

$$
T A_{i t}=\beta 1+\beta 2 \Delta \mathrm{REV}_{i t}+\beta 3 P P E_{i t}+\varepsilon_{i t}
$$

3. Melakukan skala data dengan cara semua variabel tersebut dibagi dengan asset tahun sebelumnya $\left(\mathrm{A}_{\mathrm{it}}-1\right)$, sehingga formulasinya berubah menjadi :

$$
\frac{T A_{i t}}{A_{i t}-1}=\beta 1 \frac{1}{A_{i t}-1}+\beta 2 \frac{\Delta \text { Revit }}{\text { Ait }-1}+\beta 3 \frac{\text { PPEit }}{\text { Ait }-1}+\varepsilon \text { it }
$$

4. Menghitung nilai NDA dengan formulasi :

$$
\frac{N D A_{i t}}{A_{i t}-1}=\beta_{1} \frac{1}{A_{i t}-1}+\beta_{2}\left(\frac{\Delta R E V_{i t}}{A_{i t}-1}-\frac{\Delta R E C_{i t}}{A_{i t}}\right)+\beta_{3} \frac{P P E_{i t}}{A_{i t}-1}+\varepsilon_{i t}
$$

5. Nilai parameter $\beta_{1}, \beta_{2}, \beta_{3}$ adalah hasil dari perhitungan pada langkah ke 2 Menentukan nilai akrual diskresioner yang merupakan indikator manajemen laba 


\section{Risisnaci}

Vol. 1 No. 3 September 2021

akrual dengan cara mengurangi total akrual dengan akrual non diskresioner, dengan formula sebagai berikut :

Keterangan :

$$
D A_{i t}=T A_{i t}+N D A_{i t}
$$

$A_{i t} \quad:$ Total aset perusahaan i pada periode $\mathrm{t}$

$N I_{i t} \quad:$ Laba bersih perusahaan i pada periode $\mathrm{t}$

$\mathrm{CFO}_{\text {it }} \quad$ : Arus kas operasi perusahaan i pada periode $\mathrm{t}$

$N D A_{i t}$ : Akrual non diskresionerperusahaan i pada periode $\mathrm{t}$

$T A_{i t} \quad:$ Akrual diskresioner perusahaan i pada periode $\mathrm{t}$

$T A_{i t}-1 \quad$ : Total asset perusahaan i pada periode $\mathrm{t}-1$

$\triangle R E V_{i t} \quad:$ Perubahan penjualan bersih perusahaan i pada periode $\mathrm{t}$

$\triangle R E C_{i t} \quad:$ Perubahan piutang perusahaan i pada periode $\mathrm{t}$

$P P E_{i t} \quad:$ Property, Plant and Equipment perusahaan i pada periode $\mathrm{t}$

$\beta_{1}, \beta_{2}, \beta_{3} \quad$ : Parameter yang diperoleh dari persamaan regresi

$\varepsilon_{i t} \quad:$ error term perusahaan i pada periode

\section{Manajemen Laba Riil (Real Earnings Management)}

Real Earnings Management (REM). Dengan menggunakan model pengukuran yang dikembangkan oleh Roychowdhury (2006), diantaranya sebagai berikut :

1. Menghitung rekayasa penjulan

$$
A B C F O_{i t}=C F O \text { Aktual }- \text { CFO Normal }
$$

CFO aktual diperoleh dari nilai arus kas dari aktivitas operasi pada laporan arus kas perusahaan, sedangkan CFO normal $\left(\frac{C F O_{i t}}{A_{i t}-1}\right)$ diperoleh melalui persamaan regresi (Dewi dan Herusetya, 2015) :

$$
\frac{C F O_{i t}}{A_{i t}-1}=\beta_{0}+\beta_{1}\left(\frac{1}{A_{i t}-1}\right)+\beta_{3}\left(\frac{\Delta S_{i t}}{A_{i t}-1}\right)+\varepsilon_{i t}
$$

2. Menghitung rekayasa melalui pengurangan beban diskresioner :

$$
A B D I S E X P_{i t}=\text { DISEXP Aktual }- \text { DISEXP Normal }
$$

DISEXP aktual diperoleh dari beban penelitian dan pengembangan, serta beban administrasi, penjualan, dan umum. DISEXP normal $\left(\frac{\text { ISEXP }_{i t}}{A_{i t}-1}\right)$ diperoleh melalui persamaan regresi (Dewi \& Herusetya, 2015)

$$
\frac{D I S E X P_{i t}}{A_{i t}-1}=\beta_{0}+\beta_{1}\left(\frac{1}{A_{i t}-1}\right)+\beta_{2}\left(\frac{S_{i t}-1}{A_{i t}-1}\right)+\varepsilon_{i t}
$$

3. Menghitung produksi berlebih

$$
A B P R O D_{i t}=P R O D \text { Aktual }-P R O D \text { Normal }
$$

PROD aktual diperoleh dari: $C O G S_{t}+\triangle I N V_{t}$. Dan PROD normal $\left(\frac{P R O D_{t}}{A_{t}-1}\right)$ diperoleh melalui persamaan regresi sebagai berikut (Dewi \& Herusetya, 2015):

$$
\begin{aligned}
\frac{P R O D_{i t}}{A_{i t}-1}=\beta_{0} & +\beta_{1}\left(\frac{1}{A_{i t}-1}\right)+\beta_{2}\left(\frac{S_{i t}}{A_{i t}-1}\right)+\beta_{3}\left(\frac{\Delta S_{i t}}{A_{i t}-1}\right)+\beta_{4}\left(\frac{\Delta S_{i t}-1}{A_{i t}-1}\right) \\
& +\varepsilon_{i t}
\end{aligned}
$$

Keterangan :

$A B C F O_{i t} \quad$ : Arus kas operasi abnormal pada perusahaan $\mathrm{i}$ tahun $\mathrm{t}$

$A B D I S E X P_{i t}$ : Beban diskresioner abnormal pada perusahaan i tahun

$A B P R O D_{i t} \quad$ : Beban produksi abnormal pada perusahaan i tahun $\mathrm{t}$

$\mathrm{CFO}_{i t} \quad$ : Arus kas operasi (Cash Flow from Operation) pada perusahaan i tahun $\mathrm{t}$ 
$P R O D_{i t} \quad$ : Beban pokok penjualan ditambah perubahan dalam persediaan pada perusahaan i tahun $\mathrm{t}$

COGS $_{\text {it }} \quad$ : Beban pokok penjualan pada perusahaan i tahun $\mathrm{t}$

$\Delta I N V_{i t} \quad$ : Perubahan persediaan pada perusahaan i tahun $\mathrm{t}$ yang dihitung dengan persediaan tahun $\mathrm{t}$ - persediaan tahun $\mathrm{t}-1$

$S_{i t} \quad:$ Penjualan bersih pada perusahaan i tahun $\mathrm{t}$

$\Delta S_{i t}-1 \quad$ : Perubahan penjualan bersih pada perusahaan i tahun $\mathrm{t}-1$ yang dihitung dengan penjualan bersih tahun $\mathrm{t}-1$ - penjualan bersih tahun $\mathrm{t}-2$

$A_{i t} \quad:$ Total aset perusahaan i pada periode $\mathrm{t}$

$\beta_{1}, \beta_{2}, \beta_{3} \quad$ : Parameter yang diperoleh dari persamaan regresi

$\varepsilon_{i t} \quad:$ error term perusahaan i pada periode

Untuk menghitung nilai REM (Real Earnings Management), maka seluruh nilai dari standardized variables CFO, PROD, dan DISXEP harus dijumlahkan. Dalam melakukan penjumlahan, nilai standardized PROD harus dikalikan dengan -1 terlebih dahulu sebelum nilai standardized ketiganya dijumlahkan. Hal ini dilakukan dengan tujuan membalik arah atau menyelaraskan nilai PROD dengan nilai CFO dan DISXEP (Ginuny, 2015).

\section{Variabel Bebas (Independent Variable)}

Variabel bebas dalam penelitian ini adalah Female executive.

\section{Female executive}

Adapun Female executive suatu perusahaan diidentifikasi melalui Chief Executive Office (CEO), Chief Financial Officer (CFO), dan Dewan Komisaris. Dan untuk menghitung proporsi Female executive perusahaan menggunakan rumus sebagai berikut (Fathonah, 2018) :

\section{Prosedur Analisis Data}

$$
\text { Female Executive }=\frac{\text { Number of Female Executive }}{\text { Total of Executive }}
$$

Dalam penelitian ini analisis data yang digunakan pada penelitian ini menggunakan analisis kuantitatif. Prosedur analisis data pada penelitian ini dimulai dari statistik deskriptif, uji asumsi klasik, dan uji regresi linear sederhana. Analisis data dalam penelitian ini dibantu oleh aplikasi IBM SPSS 23.

\section{Statistik Deskriptif}

Statistik deskriptif dalam penelitian disajikan untuk memberikan informasi mengenai karakteristik variabel-variabel penelitian, yaitu nilai minimum, nilai maksimum, nilai rata-rata, dan standar deviasi.

\section{Uji Asumsi Klasik}

Uji asumsi klasik diperlukan untuk mengetahui apakah hasil estimasi regresi yang dilakukan benar-benar bebas dari adanya gejala disetiap uji yang dilakukan. Pengujian asumsi klasik ini menggunakan empat uji yaitu, uji normalitas, uji autokorelasi, dan uji heteroskedastisitas.

\section{Uji Normalitas}

Dalam penelitian ini akan menggunakan uji statistic one sample kolmogorov-smirnov test. Uji ini menerangkan jika nilai signifikasi Kolmogorov-Smirnov $>0,05$ maka data dinyatakan terdistribusi normal, sedangkan jika nilai signifkasi Kolmogorov Smirnov lebih kecil dari 0,05 maka data dinyatakan terdistribusi tidak normal. Apabila uji normalitas menunjukkan bahwa yang digunakan dalam penelitian ini cenderung tidak normal maka dapat digunakan asumsi Teorema Limit Sentral (Central Limit Theorem) 


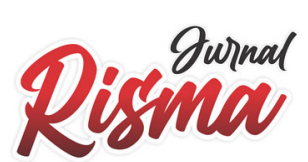

Vol. 1 No. 3 September 2021

yaitu jika jumlah observasi cukup besar ( $\mathrm{n}>30$ ), maka asumsi normalitas dapat diabaikan (Gujarati, 2003) dalam Malindasari (2016).

Uji Autokorelasi

Penelitian ini menggunakan uji durbin-watson untuk mendeteksi autokorelasi, dimana pengambilan keputusan ada tidaknya autokorelasi:

\begin{tabular}{ccc}
\hline Keterangan & Keputusan & $\begin{array}{c}\text { Nilai Durbin } \\
\text { Watson }\end{array}$ \\
\hline Tidak ada autokorelasi positif & Tolak & $0<\mathrm{d}<\mathrm{dl}$ \\
\hline Tidak ada autokorelasi positif & Tidak ada keputusan & $\mathrm{dL} \leq \mathrm{d} \leq \mathrm{dU}$ \\
\hline Tidak ada autokorelasi negatif & Tolak & $4-\mathrm{dL}<\mathrm{d}<4$ \\
\hline Tidak ada autokorelasi negatif & Tidak ada keputusan & $4-\mathrm{dU} \leq \mathrm{d} \leq 4-\mathrm{dL}$ \\
\hline $\begin{array}{c}\text { Tidak ada autokorelasi positif } \\
\text { atau negatif }\end{array}$ & $\begin{array}{c}\text { Tidak ditolak } \\
\text { (diterima) }\end{array}$ & $\mathrm{dU}<\mathrm{d}<4-\mathrm{dU}$ \\
\hline Sumber: Ghozali, 2005; 96 & &
\end{tabular}

\section{Uji Heteroskedasitas}

Pengujian ini dilakukan dengan menggunakan uji glejser, dimana jika variable independent signifikan secara statistik mempengaruhi variable dependen, maka indikasi terjadi heteroskedasitas. Hal ini terlihat dari probabilitas signifikansinya diatas tingkat kepercayaan 5\%. Jadi dapat disimpulkan model regresi tidak mengandung adanya heteroskeddasitas.

\section{Analisis Regresi Linear Sederhana}

Pada penelitian ini, pengujian dilakukan dengan analisis regresi linear sederhana, yaitu regresi sederhana didasarkan pada hubungan fungsional ataupun kausal satu variable dependen. Persamaan regresi digunakan untuk menguji pengaruh Female executive terhadap tingkat manajemen laba baik melalui manajemen laba akrual maupun manajemen laba riil. Persamaan tersebut adalah sebagai berikut:

Persamaan Regresi Manajemen Laba Akrual

$\mathrm{DA}=\alpha+\beta 1 \mathrm{FE}+\varepsilon$

Persamaan Regresi Manajemen Laba Riil

$\mathrm{REM}=\alpha+\beta 1 \mathrm{FE}+\varepsilon$

Keterangan :

DA : Discretionary Accruals

REM : Real Earning Management

FE : Female executive

$\alpha \quad$ : Koefisien regresi konstanta

$\beta_{1} \quad$ : Koefisien regresi masing-masing proksi.

$\varepsilon \quad:$ Error term

\section{Uji Hipotesis}

\section{Koefisien Determinasi $\left(\mathbf{R}^{2}\right)$}

Koefisien Determinasi $\left(\mathrm{R}^{2}\right)$ bertujuan untuk menguji tingkat keeratan atau keterikatan antara variabek dependen dan variabel independen yang bisa dilihat dari besarnya nilai koefisien determinan determinasi (R-square).

\section{Uji Signifikansi Parameter Individual (Uji t)}

Uji $t$ adalah pengujian secara statistik untuk mengetahui apakah variable independen secara individual mempunyai pengaruh terhadap variabel dependen. Kriteria pengambilam keputusan adalah apabila t hitung $>\mathrm{t}$ tabel dan tingkat signifikansi $(\alpha)<$ 0,05 maka $\mathrm{H}_{0}$ yang menyatakan bahwa tidak terdapat pengaruh variabel independen secara parsial terhadap variabel dependen ditolak. Dan apabila $t$ hitung $<t$ tabel dan tingkat signifikansi $(\alpha)>0,05$ maka $\mathrm{H}_{0}$ diterima. 


\section{Uji Beda $\mathbf{t}$ - test}

Uji beda t-test digunakan untuk menentukan apakah dua sample yang tidak berhubungan memiliki nilai rata-rata berbeda. Uji beda t-test dilakukan dengan cara membandingkan perbedaan antara dua nilai rata-rata dengan standar error dari perbedaan rata-rata dua sample. Jika probabilitas $>0,05$ maka Ho diterima dan Ha ditolak berarti tidak terdapat perbedaan yang signifikan. Jika probabilitas $<0,05$ maka Ho ditolak dan Ha diterima terdapat perbedaan yang signifikan.

\section{HASIL DAN PEMBAHASAN}

\section{Gambaran Umum Objek Penelitian}

Perusahaan manufaktur yang terdaftar di BEI selama periode 2016 - 2018 adalah sejumlah 152 perusahaan. Berdasarkan hasil purposive sampling yang dilakukan diperoleh 50 perusahaan yang memenuhi kriteria, sehingga data observasi yang diperoleh selama 3 tahun pengamatan adalah sejumlah 150 perusahaan.

\section{Analisis Statistik Deskriptif}

Analisis ini bertujuan untuk memberikan gambaran secara umum mengenai semua variabel yang digunakan pada penelitian ini. Adapun hasil dari analisis ini dapat dilihat pada tabel 2 sebagai berikut :

Tabel 2. Statistic Deskriptif

\begin{tabular}{lccccc}
\hline & N & Minimum & Maximum & Mean & Std. Deviation \\
\hline FE & 150 & 0.3333 & 1.0000 & 0.426667 & 0.1643916 \\
\hline DA & 150 & -0.9265 & 0.1929 & -0.016114 & 0.1031858 \\
\hline REM & 150 & 6.7864 & 27.9616 & 19.951633 & 5.0305842 \\
\hline Valid N (listwise) & 150 & & & & \\
\hline
\end{tabular}

Sumber: data diolah 2020

Variabel independen yang diproksikan dengan female executive dapat dilihat bahwa $\mathrm{N}$ menunjukkan data setiap variabel yang valid berjumlah 150 , dari 150 data tersebut diketahui, nilai minimum dan maximum berturut-turut untuk variabel female executive adalah sebesar 0.3333 yang merupakan nilai terendah dalam variabel female executive dan nilai sebesar 1.0000 merupakan nilai tertinggi dalam variabel female executive. Sedangkan nilai rata-rata untuk variable independen yang diproksikan dengan female executive menunjukkan nilai rata-rata 0.426667 nilai rata-rata tersebut menunjukkan bahwa rata-rata presentase female executive yang dimiliki perusahaan adalah sedikit, dengan standar deviasi sebesar 0.1643916. Nilai standar deviasi yang lebih kecil daripada nilai rata-rata yang menunjukkan bahwa Female executive yang menjadi sampel pada penelitian ini memiliki penyimpangan data yang rendah yang artinya penyebaran nilainya merata.

Variabel Dependen yang diproksikan dengan Discretionary accruals dan Real earnings management masing-masing memiliki nilai rata-rata sebesar -0.016114 dan 19.951633, dapat dilihat nilai rata-rata untuk discretionary accruals bernilai negative yang artinya pada nilai negative pada angka ini menunjukan perusahaan melakukan manajemen laba dengan pola penurunan laba perusahaan dimana semakin tinggi nilai discretionary accruals berarti semakin tinggi pula laba yang dikurangi, sedangkan pada real earnings management diketahui nilai rata-ratanya bernilai positif dimana nilai positif tersebut menunjukan bahwa perusahaan melakukan manajemen laba dengan pola penaikan laba perusahaan, dimana apabila semakin besar nilai real earning management maka semakin tinggi juga laba yang ditambahkan pada laporan keuangan. 


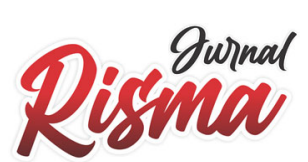

Vol. 1 No. 3 September 2021

Adapun nilai standar deviasi dari Discretionary accruals dan Real earnings management berturut-turut sebesar 0.10318578 dan 5.0305842. Nilai standar deviasi variable Discretionary accruals lebih besar daripada nilai rata-rata menunjukkan bahwa terdapat variasi pada variable Discretionary accruals. Sedangkan pada Real earnings management nilai standar deviasinya lebih kecil daripada nilai rata-rata yang menunjukkan bahwa variable Real earnings management tidak memiliki variasi selama periode pengamatan. Dimana nilai maksimum dari kedua variable tersebut adalah 0.1929 dan 27.9616.

\section{Analisis Data Penelitian}

\section{Uji Asumsi Klasik}

\section{Uji Normalitas}

Apabila uji normalitas menunjukan bahwa data yang digunakan dalam penelitian ini cenderung tidak normal, maka penelitian ini menggunakan asumsi Central Limit Theorem. Adapun hasil pengujian baik untuk Discretionary accruals maupun Real earnings management yang digunakan adalah sebagai berikut:

Tabel 3.

Uji Normalitas

\begin{tabular}{lcc}
\hline & N & $\begin{array}{c}\text { Asymp. Sig (2- } \\
\text { tailed) }\end{array}$ \\
\hline Discretionary Accruals & 150 & 0.000 \\
\hline Real Earnings Management & 150 & 0.000 \\
\hline
\end{tabular}

Sumber : data diolah 2020

Berdasarkan Tabel 3 tersebut didapatkan hasil bahwa nilai Asymp. Sig (2-tailed) dari uji normalitas female executive terhadap discretionary accruals dan real earnings management menunjukkan nilai sebesar 0.000 yang mana nilai tersebut lebih kecil dari $\alpha$ $=0.05$, yang artinya kedua data tersebut tidak berdistribusi secara normal. Namun merujuk pada asumsi Teorema Limit Sentral (Central Limit Theorem) yang dijelaskan Gujarati (2003) dalam Malindasari (2016) yang menyatakan bahwa untuk sampel yang besar terutama lebih dari $30(n>30)$, distribusi sampel dianggap mendekati distribusi normal yang berarti bahwa walaupun dari pengujian asumsi klasik berupa pengujian normalitas menunjukkan bahwa ada data berdistribusi tidak normal namun karena observasi lebih dari $30(n>30)$ maka data tersebut tetap dianggap normal, dimana dalam penelitian ini sampel yang digunakan adalah sebanyak 150 perusahaan.

Uji Autokorelasi

Dalam penelitian ini uji autokorelasi dilakukan dengan menggunakan uji Durbin Watson. Berikut merupakan hasil dari uji autokorelasi :

Tabel 4.

Uji Autokorelasi

\begin{tabular}{lc}
\hline & Durbin Watsons \\
\hline Discretionary Accruals & 1.830 \\
\hline Real Earnings Management & 0.712 \\
\hline
\end{tabular}

Sumber : data diolah 2020

Nilai dU dan dL pada penelitian ini sebesar 1.7465 dan 1.7197. Adapun hasil pengujian autokorelasi untuk variabel dependen discretionary accruals pada tabel 4 diketahui nilai Durbin-Watson sebesar 1.830 dimana nilai tersebut tergolong pada $\mathrm{dU}<\mathrm{d}<4-\mathrm{dU}$; yaitu $1.7465<1.830<2.2535$ yang artinya tidak ada autokorelasi positif atau negatif, dengan kata lain dapat disimpulkan bahwa tidak terdapat autokorelasi. 
Hasil pengujian autokorelasi untuk variabel dependen Real earnings management menunjukkan nilai Durbin-Watson sebesar 0.712 dimana nilai tersebut tergolong pada 0 $<\mathrm{d}<\mathrm{dL}$; yaitu $0<0.712<1.7197$ menunjukkan bahwa tidak ada autokoralsi positif ditolak yang artinya terdapat autokorelasi positif terhadap real earnings management.

\section{Uji Heteroskedasitas}

Adapun hasil uji dari heteroskedasitas dalam penelitian ini adalah :

Tabel 5.

Uji Heteroskedasitas

\begin{tabular}{lcc}
\hline & $\begin{array}{c}\text { Discretionary } \\
\text { Accruals }\end{array}$ & $\begin{array}{c}\text { Real Earnings } \\
\text { Management }\end{array}$ \\
\cline { 2 - 3 } & Sig. & Sig. \\
\hline (Constant) & 0.002 & 0.002 \\
\hline FE & 0.942 & 0.014 \\
\hline
\end{tabular}

Sumber : data diolah 2020

Hasil pengujian dari pengujian glejser dari female executive terhadap Discretionary accruals pada tabel 5 diketahui nilai Sig. female executive sebesar 0.942, dimana nilai signifikansi tersebut lebih besar dibandingkan dengan 0.05 yang artinya tidak terjadi heteroskedasitas pada variable discretionary accruals. Sedangkan untuk female executive terhadap real earnings management dari hasil pengujian menunjukkan nilai Sig. female executive sebesar 0.014 , yang mana nilai signifikansi lebih kecil dibandingkan dengan 0.05 yang menunjukkan bahwa terjadi heteroskedasitas terhadap real earnings management.

\section{Analisis Regresi Linear Sederhana}

Analisis regresi linier sederhana digunakan untuk mengukur pengaruh variable bebas terhadap variabel terikat. Di katakan linier karena setiap estimasi atas nilai diharapkan mengalami peningkatan atau penurunan mengikuti garis lurus. Hasil analisis regresi adalah berupa koefisien untuk masing-masing variable independen.

Analisis Regresi Sederhana Female executive terhadap Manajemen Laba Akrual

Tabel 6.

Regresi Sederhana Discretionary accruals

\begin{tabular}{lcc}
\hline \multicolumn{2}{c}{$\begin{array}{c}\text { Unstantardized } \\
\text { Coefficients }\end{array}$} \\
\hline (Constant) & B & Std. Error \\
\hline FE & -0.044 & 0.023 \\
\hline
\end{tabular}

Sumber : Lampiran 3.1

Berdasarkan perhitungan hasil analisis regresi sederhana, pada tabel 6 kolom unstandardized coefficients diperoleh nilai $\alpha$ (constant) sebesar -0.044 dan $\beta$ sebesar 0.066 sehingga dapat dibentuk persamaan regresi sebagai berikut:

$\mathrm{DA}=-0.044+0.066 \mathrm{FE}+\varepsilon$

Berdasarkan persamaan tersebut dapat disimpulkan :

1) Nilai $\alpha$ (konstanta) sebesar -0.044 menyatakan bahwa jika nilai female executive sama dengan 0 atau variabel female executive tidak ada, maka nilai variabel discretionary accruals adalah sebesar -0.044

2) Merupakan koefisien regresi 0.066 yang menunjukkan bahwa setiap pertambahan variabel female executive sebanyak 1 poin maka hal tersebut akan meningkatkan variabel discretionary accruals sebesar 0.066 . 


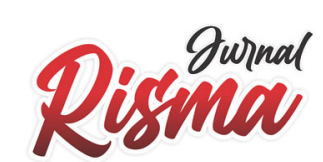

Vol. 1 No. 3 September 2021

Dari persamaan di atas adalah bahwa koefisien regresi female executive (FE) memiliki tanda positif 0.066 , yaitu mengandung arti bahwa terjadi hubungan positif antara female executive dengan variabel discretionary accruals. Yang berarti semakin bertambah nilai female executive maka akan meningkatkan variabel discretionary accruals.

Analisis Regresi Sederhana Female executive terhadap Manajemen Laba Riil

Tabel 7.

\begin{tabular}{lcc} 
Regresi Sederhana Real earnings management \\
\multicolumn{2}{c}{$\begin{array}{c}\text { Unstantardized } \\
\text { Coefficients }\end{array}$} \\
\hline B & Std. Error \\
\hline FE & 22.947 & 1.119 \\
\hline
\end{tabular}

Sumber : data diolah 2020

Berdasarkan perhitungan hasil analisis regresi sederhana, dilihat dari tabel 7 diperoleh nilai $\alpha$ sebesar 22.947 dan $\beta$ sebesar -7.020 sehingga dapat dibentuk persamaan regresi sebagai berikut:

$\mathrm{REM}=22.947+(-7.020) \mathrm{FE}+\varepsilon$

Berdasarkan persamaan tersebut dapat disimpulkan :

1) Nilai $\alpha$ (konstanta) sebesar 22.947 menyatakan bahwa jika nilai female executive sama dengan 0 atau variabel female executive tidak ada, maka nilai variabel real earnings management adalah sebesar 22.947.

2) Merupakan koefisien regresi -7.020 yang menunjukkan bahwa setiap pertambahan variabel female executive sebanyak 1 poin maka hal tersebut akan meningkatkan variabel real earnings management sebesar -7.020.

Dari persamaan di atas adalah bahwa koefisien regresi female executive (FE) memiliki tanda negatif -7.020, yaitu mengandung arti bahwa terjadi hubungan negatif antara female executive dengan variabel real earnings management. Yang berarti semakin bertambah nilai female executive maka akan menigurangi variabel real earnings management.

Analisis Uji Hipotesis

Koefisien Determinasi $\mathbf{R}^{2}$

Adapun nilai koefisien determinasi pada penelitian ini dapat dilihat pada tabel output berikut :

Koefisien Determinasi Female executive terhadap Manajemen Laba Akrual

Tabel 8.

Koefisien Determinasi Discretionary Accruals

\begin{tabular}{lcc}
\hline Model & R & R Square \\
\hline $\mathbf{1}$ & 0.106 & 0.011 \\
\hline
\end{tabular}

Sumber : data diolah 2020

Berdasarkan tabel 8 tersebut, nilai R-Square menunjukkan angka 0.011. Nilai R-Square sebesar 0.011 ini didapat dari pengkuadratan nilai koefisien korelasi $\mathrm{R}$ yaitu 0.106 x 0.106 mendapatkan nilai sebesar 0.011. Besarnya angka koefisien determinasi adalah sebesar 0.011 atau sama dengan $1,1 \%$, nilai sebesar tersebut mengandung arti bahwa variable female executive berpengaruh terhadap variable manajemen laba akrual sebesar $1,1 \%$ sedangkan sisanya $98,9 \%$ dipengaruhi oleh variable lain diluar persamaan regresi ini atau variable yang tidak diteliti. 


\section{Koefisien Determinasi Female executive terhadap Manajemen Laba Riil}

Tabel 9.

Koefisien Determinasi Real earnings management

\begin{tabular}{lcc}
\hline Model & R & R Square \\
\hline $\mathbf{1}$ & 0.229 & 0.053 \\
\hline
\end{tabular}

Sumber : data diolah 2020

Nilai R-Square pada table 9 menunjukkan nilai sebesar 0.053, yang mana nilai ini didapat dari pengkuadratan nilai koefisien korelasi R yaitu 0.229 x 0.229 sehingga mendapatkan nilai sebesar 0.053. Besarnya angka koefisien determinasi tersebut sama dengan 5,3\%, nilai tersebut mengandung arti bahwa variable female executive berpengaruh terhadap variable manajemen laba riil sebesar 5,3\% sedangkan sisanya 94,7\% dipengaruhi oleh variable lain diluar persamaan regresi ini atau variable yang tidak diteliti.

\section{Analisis Uji Signifikansi Parameter Individual (Uji t)}

Apabila $t$ hitung $>$ t tabel dan tingkat signifikansi $(\alpha)<0.05$ maka secara parsial variable independen berpengaruh terhadap variable dependen, dan sebaliknya apabila $t$ hitung $<t$ tabel maka variable independen tidak berpengaruh terhadap variable dependen. Adapaun hasil dari pengujian t pada penelitian ini adalah sebagai berikut :

\section{Uji t Female executive terhadap Manajemen Laba Akrual}

Tabel 10.

Uji t Discretionary Accruals

\begin{tabular}{lc}
\hline Model & T \\
\hline (Constant) & -1.895 \\
\hline FE & 1.294 \\
\hline
\end{tabular}

Sumber : data diolah 2020

Berdasarkan tabel 10 tersebut dapat diketahui bahwa nilai thitung untuk female executive adalah sebesar 1.294. Dimana nilai ini akan dibandingkan dengan nilai $t$ tabel pada tabel distribusi t. Dengan jumlah sampel yang ada pada penelitian ini adalah berjumlah 150 , jumlah variable sebesar 1 , dan taraf signifikansi sebesar 0.05 , serta derajat kebebasan pada penelitian ini $\mathrm{df}=\mathrm{n}-\mathrm{k}=150-1=149$ sehingga diperoleh nilai $\mathrm{t}$ tabel sebesar 1.796. Nilai $t$ hitung dan $\mathrm{t}$ tabel tersebut dapat digambarkan sebagai berikut :

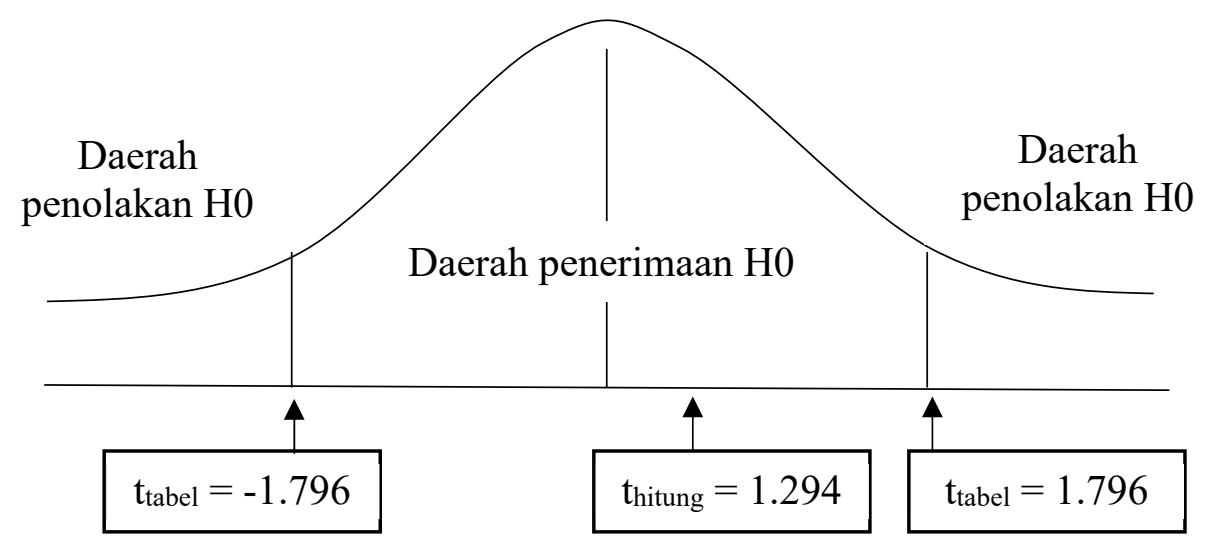

Gambar 2. Daerah penerimaan dan penolakan H0

Berdasarkan gambar 2 dapat diketahui nilai t hitung berada di daerah penerimaan $\mathrm{H} 0$ yang artinya nilai t hitung lebih kecil dibandingkan dengan nilai t tabel yaitu sebesar $1.294<$ 1.796 sehingga dapat disimpulkan bahwa H0 diterima dan Ha ditolak yang artinya tidak 


\section{Risinaw}

Vol. 1 No. 3 September 2021

terdapat pengaruh yang signifikan dari female executive terhadap manajemen laba akrual pada perusahaan manufaktur yang terdaftar di Bursa Efek Indonesia periode 2016 - 2018. Uji t Female executive terhadap Manajemen Laba Riil

Tabel 11.

Uji t Real earnings management

\begin{tabular}{lc}
\hline Model & $\mathbf{t}$ \\
\hline (Constant) & 20.507 \\
\hline FE & -2.867 \\
\hline
\end{tabular}

Sumber : data diolah 2020

Tabel 11 tersebut menunjukkan nilai t hitung untuk female executive adalah sebesar -2.867. Dimana nilai ini akan dibandingkan dengan nilai t tabel pada tabel distribusi t. Dengan jumlah sampel yang ada pada penelitian ini adalah berjumlah 150 , jumlah variable sebesar 1 , dan taraf signifikansi sebesar 0.05 , serta derajat kebebasan pada penelitian ini $\mathrm{df}=\mathrm{n}-\mathrm{k}=150-1=149$ sehingga diperoleh nilai t tabel sebesar 1.796. Nilai t hitung dan $t$ tabel tersebut dapat digambarkan sebagai berikut :

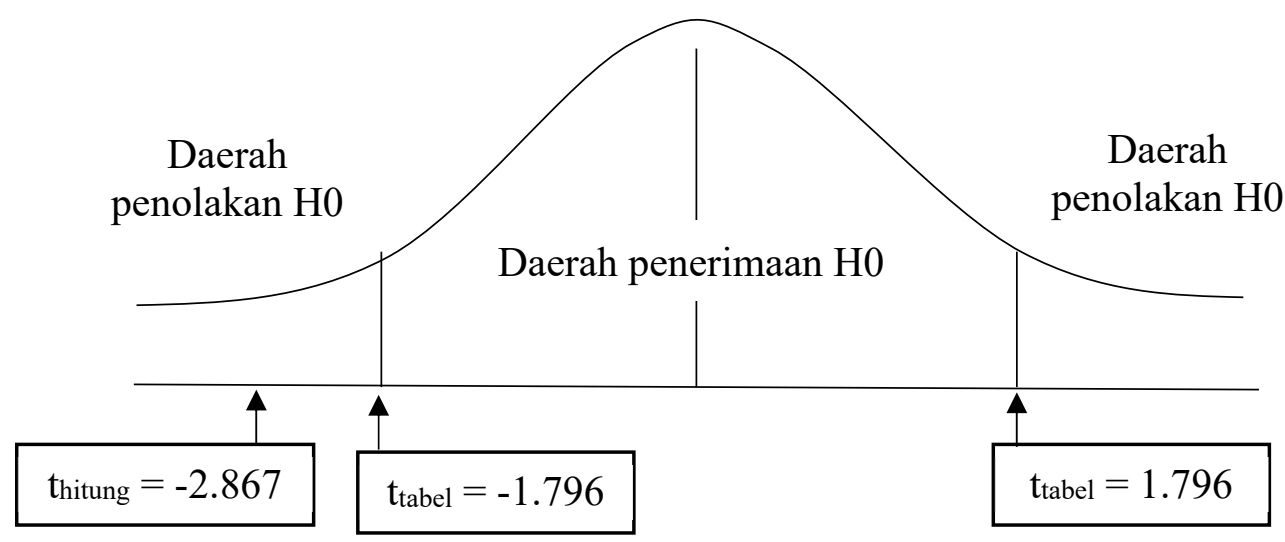

Gambar 3. Daerah Penerimaan dan Penolakan H0

Berdasarkan gambar 3 dapat diketahui bahwa nilai t hitung berada di daerah penolakan $\mathrm{H} 0$ yang artinya nilai t hitung lebih besar dibandingkan dengan nilai t tabel yaitu -2.867 $>-1.796$ sehingga dapat disimpulkan bahwa H0 ditolak dan Ha diterima yang artinya terdapat pengaruh yang signifikan dari female executive terhadap manajemen laba riil pada perusahaan manufaktur yang terdaftar di Bursa Efek Indonesia periode 2016 - 2018.

\section{Analisis Uji Beda t test}

Uji beda $t$ test bertujuan untuk membandingkan rata-rata dua grup yang tidak berhubungan satu dengan yang lain. Dimana uji beda $t$ test pada penelitian ini akan menghasilkan 2 output dimana output pertama akan memberikan gambaran umum mengenai variabel female executive berdasarkan kelompok, sedangkan pada output kedua yang merupakan output utama dari uji beda $t$ test pada penelitian ini akan memberikan hasil apakah pernyataan dari output pertama pada uji ini signifikan atau tidak. Adapun hasil analisis uji beda t test, didapatkan hasil sebagai berikut :

Tabel 12. Uji Beda t Test

\begin{tabular}{lcc}
\hline & FE & Mean \\
\hline DA & $>=0.6667$ & -0.011400 \\
\hline & $<0.6667$ & -0.016211 \\
\hline REM & $>=0.6667$ & 20.526273 \\
\hline & $<0.6667$ & 19.939906 \\
\hline
\end{tabular}

Sumber : data diolah 2020 
Berdasarkan tabel 12 dapat diketahui untuk kelompok female executive yang $>=$ 0.6667 dan $<0.6667$. Adapun untuk variabel discretionary accruals diketahui nilai ratarata untuk proporsi female executive yang $>=0.6667$ adalah sebesar -0.011400 sedangkan untuk proporsi female executive yang $<0.6667$ adalah sebesar -0.016211 . Apabila dilihat dari nilai rata-rata kedua variabel baik discretionary accruals dan real earnings management dapat dilihat bahwa nilai rata-rata baik untukk female executive $>=0.6667$ dan $<0.6667$ untuk discretionary accruals dan real earnings management terdapat perbedaan, dimana rata-rata untuk variabel discretionary accruals lebih kecil dibandingkan dengan real earnings management. Dari perbedaan kedua nilai rata-rata baik untuk discretionary accruals maupun real earrnings management tersebut dapat diketahui bahwa perusahaan manufaktur pada penelitian ini cenderung menggunakan real earning management dalam melakukan manajemen laba.

Tabel 13. Uji Beda t Test

\begin{tabular}{lllcc}
\hline \multirow{2}{*}{ DA } & & $\begin{array}{c}\text { Levene's Test For } \\
\text { Equality Of Variances }\end{array}$ & $\begin{array}{c}\text { t-test for } \\
\text { Equality } \\
\text { of Means }\end{array}$ \\
\cline { 3 - 5 } & $\begin{array}{l}\text { Equal Variance } \\
\text { Assumed }\end{array}$ & 0.118 & 0.731 & 0.937 \\
\cline { 2 - 5 } & $\begin{array}{l}\text { Equal Variances not } \\
\text { assumed }\end{array}$ & & & \\
\hline REM & $\begin{array}{l}\text { Equal Variance } \\
\text { Assumed }\end{array}$ & 0.427 & 0.515 & 0.842 \\
\cline { 2 - 5 } & $\begin{array}{l}\text { Equal Variances not } \\
\text { assumed }\end{array}$ & & & \\
\hline
\end{tabular}

Sumber : data diolah 2020

Terlihat dari output SPSS pada tabel 13 bahwa F hitung levene test untuk variabel discretionary accruals dan real earnings management yaitu berturut-turut sebesar 0.118 dan 0.427 dengan probabilitas 0.731 dan 0.515 karena probabilitas kedua variabel dependen baik discretionary accruals maupun real eaarnings management $>0.05$ maka dapat disimpulkan bahwa data kedua variabel dependen memiliki variance yang sama, Berdasarkan tabel 16 pada uji beda t test ini pada bagian equal variance assumed yang menunjukkan nilai probabilitas signifikansi (two tailed) untuk variabel discretionary accruals dan real earnings management yaitu sebesar 0.937 dan 0.842 maka sebagaimana dasar pengambilan keputusan pada pengujian ini dapat disimpulkan bahwa H0 diterima dan Ha ditolak karena nilai signifikansi (2-tailed) untuk kedua variabel berada $>0.05$ yang berarti tidak ada perbedaan dari female executive terhadap manajemen laba baik melalui pendekatan akrual maupun riil.

\section{Pembahasan}

Penelitian ini bertujuan untuk mengetahui pengaruh dari female executive terhadap manajemen laba baik melalui pendekatan discretionary accruals maupun real earnings management.

Pengaruh Female executive terhadap Manajemen Laba melalui pendekatan Akrual

Berdasarkan uji yang telah dilakukan dapat menyimpulkan bahwa female executive tidak berpengaruh terhadap manajemen laba. Hasil ini ditunjukkan dari nilai $\mathrm{t}$ hitung yang lebih kecil dibandingkan dengan nilai t tabel yaitu sebesar $1.294<1.796$ dan nilai sginifikansi sebesar 0.198 lebih besar dibandingkan dengan 0.05 sehingga dapat tidak terdapat pengaruh yang signifikan dari female executive terhadap manajemen laba 


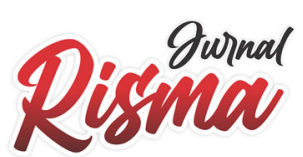

Vol. 1 No. 3 September 2021

akrual pada perusahaan manufaktur yang terdaftar di Bursa Efek Indonesia periode 2016 - 2018 dan juga melihat nilai rata-rata pada statistic deskriptif, nilai rata-rata untuk variabel discretionary accruals yaitu sebesar -0.016114 dimana nilai tersebut adalah nilai yang rendah sehingga dapat juga menjadi factor female executive tidak berpengaruh terhadap discretionary accruals. Dan nilai R Square yang dihasilkan dari uji koefisien determinasi pada hipotesis ini juga memiliki nilai sebesar $1,1 \%$ yang mana nilai tersebut merupakan pengaruh yang diberikan female executive terhadap manajemen laba, nilai ini juga merupakan factor mengapa female executive tidak berpengaruh terhadap manajemen laba melalui pendekatan akrual.

Hasil pengujian ini sejalan dengan penelitian Damayanti, dkk (2020) yang memberikan hasil bahwa hanya Female CEO yang berpengaruh sedangkan CFO maupun Dewan Komisaris wanita tidak berpengaruh terhadap manajemen laba melalui discretionary accruals. Perusahaan yang memiliki CEO seorang wanita kemungkinan dapat menurunkan perilaku manajemen laba diperusahaan, karena wanita memiliki sifat lebih berhati hati, menghindari resiko dan memiliki standar etika lebih tinggi sehingga mampu meredam motivasi untuk melakukan manajemen laba.

\section{Pengaruh Female executive terhadap Manajemen Laba melalui pendekatan Riil}

Berdasarkan dari hasil uji yang dilakukan, dimana hasil pengujian menunjukkan bahwa nilai t hitung lebih besar dibandingkan dengan nilai t tabel yaitu $-2.867>-1.796$ dan nilai sginifikansi sebesar 0.005 lebih kecil dibandingkan dengan 0.05 sehingga dapat disimpulkan bahwa $\mathrm{H0}$ ditolak dan $\mathrm{Ha}$ diterima yang artinya terdapat pengaruh yang signifikan dari female executive terhadap manajemen laba riil pada perusahaan manufaktur yang terdaftar di Bursa Efek Indonesia periode 2016 - 2018, dan jika melihat nilai rata-rata pada statistic deskriptif untuk variabel real earnings management yaitu sebesar 19.951633 dimana nilai rata-rata tersebut merupakan nilai yang cukup tinggi sehingga dapat menjadi faktor female executive berpengaruh terhadap manajemen laba. Adapun nilai $\mathrm{R}$ Square yang dihasilkan oleh pengujian koefisien determinasi $\mathrm{r}^{2}$ untuk hipotesis ini memiliki nilai sebesar 5,3\% dimana nilai lebih tinggi dibandingkan dengan nilai R Square discretionary accruals namun nilai tersebut juga tidak jauh berbeda dengan nilai $\mathrm{R}$ Square discretionary accruals, tetapi jika melihat nilai rata-rata pada statistic deskriptif, untuk variabel real earnings management memiliki nilai yang jauh lebih tinggi dari discretionary accruals yang menjadikan female executive berpengaruh terhadap manajemen laba melalui pendekatan riil. Hasil penelitian ini sejalan dengan penelitian yang dilakukan Fransisca dan Hery (2015) yang menyatakan bahwa proporsi dewan komisaris independen dan Chieffinancial officer berpengaruh siginfikan dan negatif pada real earnings management.

\section{Perbedaan Pengaruh Female executive terhadap Manajemen Laba melalui pendeketan Akrual maupun Riil}

Berdasarkan uji beda yang telah dilakukan, didapatkan bahwa tidak perbedaan pengaruh dari female executive terhadap manajemen laba baik melalui pendekatan akrual maupun riil pada perusahaan manufaktur yang terdaftar di Bursa Efek Indonesia (BEI) selama periode 2016 - 2018, dapat dilihat dari nilai signifikansi yang ditunjukkan oleh kedua variabel dependen baik manajemen laba akrual (discretionary accruals) maupun manajemen laba riil (real earnings management) berturut-turut sebesar 0.937 dan 0.842 yang mana kedua nilai tersebut $>0.05$ yang artinya $\mathrm{H} 0$ diterima yang berarti bahwa pengaruh yang diberikan female executive terhadap manajemen laba melalui pendekatan akrual dan riil tidak terdapat perbedaan, karena kedua variabel dependen tersebut samasama memiliki nilai probabilitas signifikansi yang lebih besar dari 0.05 . Hasil penelitian 
ini tidak sejalan dengan penelitian Murdani dan Nurmala (2014) yang mana penelitian ini menunjukkan terdapat perbedaan manajemen laba riil pada tahun 2011 dan manajemen laba riil pada tahun 2013 .

\section{PENUTUP}

\section{Simpulan}

Berdasarkan analisis data maka dapat disimpulkan bahwa penelitian ini memberikan bukti bahwa Female executive tidak berpengaruh terhadap manajemen laba melalui pendekatan akrual pada perusahaan manufaktur yang terdaftar di Bursa Efek Indonesia tahun 2016 - 2018. Female executive berpengaruh terhadap manajemen laba riil pada perusahaan manufaktur yang terdaftar di Bursa Efek Indonesia tauhn 2016 2018. Tidak terdapat perbedaan dari female executive pada perusahaan manufaktur dalam menerapkan manajemen laba baik melalui pendekatan akrual dan riil pada perusahaan manufaktur yang terdaftar di Bursa Efek Indonesia (BEI) selama periode 2016 - 2018.

\section{Saran}

Berdasarkan dari hasil analisis yang dilakukan pada penelitian ini, adapun saran untuk peneliti selanjutnya adalah dikarenakan keterbatasan jumlah $\mathrm{R}$ kuadrat yang relatif kecil dalam penelitian ini sehingga disarankan untuk menambah variabel lain dalam penelitian, juga perlu dilakukan penelitian mengenai female executive pada perusahaan non-manufaktur yang terdaftar di Bursa Efek Indonesia, serta apabila ada perusahaan yang menjadi sampel penelitian menggunakan mata uang asing hendaknya melakukan konversi dengan kurs yang sedang berlaku agar hasil dari penelitian ini menjadi lebih obyektif.

\section{DAFTAR PUSTAKA}

Adryanti, Ayu Fury. 2020. Pengaruh Pilihan Metode Manajemen Laba Akrual Dan Riil Terhadap Kinerja Keuangan Perusahaan Sektor Manufaktur. Jurnal Studi Akuntansi dan Keuangan, Vol.2, No.1.

Agustya, Dian. 2013. Pengaruh Free Cash Flow Dan Kualitas Audit Terhadap Manajemen Laba. Jurnal Akuntansi Akrual, Vol.4, No.2.

Arifin, Bustanul, Yeni Januarsi, Faoziah Ulfah. 2010. Perbedaan Kecenderungan Pengungkapan Corporate Social Responsibility: Pengujian Terhadap Rekayasa Akrual Dan Rekayasa Real. Jurnal dan Prosiding Simposium Nasional Akuntansi, Vol. 15.

Astuti, Christina Dwi, Nandha Pangestu. 2020. Kualitas Audit, Karakteristik Perusahaan Dan Manajemen Laba Riil. Jurnal Media Riset Akunansi, Auditing \& Informasi, Vol.19, No.2.

Byrnes, James P, David C. Miller, William D. Schafer. 1999. Gender Differences in Risk Taking: A Meta-Analysis. Psychological Bulletin, Vol. 125, No. 3.

Fathonah, Andina Nur. 2018. Pengaruh Gender Diversity dan Age Diversity Terhadap Kinerja Keuangan. Jurnal Riset Akuntansi Dan Keuangan, Vol. 6, No.3.

Fatimah, Dewi. 2020. Pengaruh Board Diversity terhadap Manajemen Laba. Journal of Applied Accounting and Taxation Article History, Vol.4, No.2.

Firmansyah, Amrie, Ferry Irawan. 2017. Adopsi Ifrs, Manajemen Laba Akrual Dan Manajemen Laba Riil. Jurnal Akuntansi dan Pendidikan, Vol.7, No.2.

Fransisca, Angelinda, Hery. 2015. Analisis Pengaruh Proporsi Dewan Komisaris Independen Dan Chief Financial Officer Wanita Terhadap Real Earnings 


\section{Risinar}

Vol. 1 No. 3 September 2021

Management Pada Perusahaan Manufaktur Yang Terdaftar di Bei Tahun 2010 2011. Jurnal Akuntansi, Vol.8, No.2.

Ginuny, Vivian Yuliana, Erni Ekawati. 2015. Nilai Perusahaan dan Manajemen Laba Riil - Analisis Level Spesifik Perusahaan.

Healy, Paul M. 1985. The Effect of Bonus Schemes on Accounting Decisions. Journal of Accounting and Economics, Vol.87, No.107.

Jensen, Michael C, William H. Meckling. 1976. Theory of the Firm: Managerial Behavior, Agency Costs and Ownership Structure. Journal of Financial Economics, Vol. 3. No.4.

Khotimah, Laillatul, Mardayaningrum, Rina Trisnawati. 2018. Determinan Manajemen Laba Akrual Pada Indeks Lq45 Dan Jii Periode 2010-2015. Riset Akuntansi dan Keuangan Indonesia, No.3, Vol.2.

Kurniawati. 2018. Pengaruh Status Relatif Komite Audit dan Kualitas Audit dengan Pendekatan Composite Measure terhadap Manajemen Laba Riil. Jurnal Online Insan Akuntan, Vol.3, No.1.

Krishnan, Gopal V, Linda M. Parsons. 2008. Getting to the Bottom Line: An Exploration of Gender and Earnings Quality. Journal of Business Ethics, Vol. 78, 65-76.

Malindasari, Putu, I Made Sukarta, Made Gede Wirakusuma. 2016. Pengaruh Depresiasi Nilai Rupiah pada Return Saham dan Volume Perdagangan Saham Perusahaan Multinasional di Bursa Efek Indonesia. E-Jurnal Ekonomi dan Bisnis Universitas Udayana. Vol. 5, No.12.

Mardani, Kartika Kusuma, Nurmala Ahmar. 2014. Analisis Perbedaan Manajemen Laba Riil Dengan Pendekatan Biaya Produksi Sebelum Dan Sesudah Implementasi Ifrs (Studi Empiris Pada Perusahaan Manufaktur Yang Terdaftar Di Bursa Efek Indonesia 2011-2013). Perbanas Institutional Repository.

Moffitt, Terrie E, Avshalom Caspi, Honalee Harrington, Barry J. Milne. 2002. Males on the life-course-persistent and adolescence-limited antisocial pathways: Follow-up at age 26 years. Development and Psychopathology, Vol. 14, 179-207.

Ningsih, Suhesti. 2015. Earning Management Melalui Aktivitas Riil Dan Akrual. Jurnal Akuntansi Dan Pajak, Vol.16, No.01.

Novilia, Oni, Paskah Ika Nugroho. 2016. Pengaruh Manajemen Puncak Wanita Terhadap Manajemen Laba. Dinamika Akuntansi, Keuangan dan Perbankan. Dinamika Akuntansi Keuangan Dan Perbankan, Vol.5, No.1.

Peni, Emilia, Sami Vähämaa. 2010. Female executives and earnings management. Managerial Finance. Managerial Finance Group Emerald Publishing, Vol.36, No.7.

Purnama, Hari, Anindya Setya Suciani. 2020. Female executive dan manajemen laba: Riset pada perusahaan manufaktur di Indonesia. Journal of Bussiness and Information Systems. Vol. 1, No.1.

Rakhman, Arif, Kholida Atiyatul Maula. 2018. Pengaruh Board Diversity (Ceo Wanita, Cfo Wanita, Proporsi Dewan Komisaris Wanita, Proporsi Komite Audit Wanita) Terhadap Pelanggaran Aturan Laporan Keuangan. Journal of Accounting and Finance, Vol.3, No.1.

Roychowdhury, S. 2006. Earnings Management Through Real Activities Manipulation. Journal of Accounting and Economics, Vol. 42, No.3.

Setyaningrum, Gracia Christ, Putri Savira Sabadra Sekarsari, Theresia Woro Damayanti. 2020. Pengaruh Eksekutif Wanita (Female executive) Terhadap Manajemen Laba 
(Studi Empiris Pada Perusahaan Di Bursa Efek Indonesia). Jurnal Ekonomi Dan Perbankan, Vol.4, No.1.

Suciani, Anindya Setya, Hari Purnama. 2020. Female executive dan manajemen laba: Riset pada perusahaan manufaktur di Indonesia. Journal of Business and Information Systems, Vol. 1, No. 1.

Sugiyono, Prof. Dr. 2017. Statistika Untuk Penelitian. Bandung: Alfabeta

Sulistyanto, H. Sri. 2008. Manajemen Laba: Teori dan Empiris. Jakarta: PT Gramedia Widiasarana Indonesia

Susanto, Idil Rakhmat, Jamaluddin Majid. 2017. Faktor-Faktor yang Mempengaruhi Manajemen Laba Pada Perusahaan Manufaktur di BEI. Jurnal Ilmiah Akuntansi Peradaban, Vol. 3, No. 2.

Tullah, Nur Amanah Jannah. 2018. Pengaruh Gender Dan Latar Belakang Pendidikan Ceo Terhadap Kinerja Keuangan Perusahaan Go Publik Yang Terdaftar Di Bursa Efek Indonesia. Jurnal Akuntansi Akunesa, Vol. 6, No.1.

Walt, N.T Van Der, Coral Ingley. 2003. Board Configuration: Building Better Boards. Corporate Governance International Journal of Business in Society, Vol. 3, No. 4: 5-17.

Wijaya, Anggita Langgeng, Anny Widasmara, Roisatul Mabruroh. 2020. Pengaruh Manajemen Puncak Wanita Terhadap Manajemen Laba Dengan Good Corporate Governance Sebagai Variabel Moderasi (Studi Empiris Pada Perusahaan Manufaktur Yang Tercatat Di Bursa Efek Indonesia Tahun 2015-2017). Seminar Inovasi Manajemen, Bisnis Dan Akuntansi, Vol.1, No.1. 